\title{
DICROCOELIUM DENDRITICUM INFECTION IN A PATIENT WITH CHRONIC SCHISTOSOMIASIS HAEMATOBIUM
}

By

OSAMA H. ABD ELLA ${ }^{1 *}$, AND ABDALLAH E. MOHAMMAD ${ }^{2}$

Departments of Medical Parasitology ${ }^{1}$, and Clinical Pathology ${ }^{2}$, Faculty of Medicine, Qena South Valley University ( ${ }^{*}$ Correspondence: osamaabdella@yahoo.com)

\section{Abstract}

Infection with Dicrocoelium dendriticum in humans is seldom to be reported in Egypt. This liver fluke, which commonly infects ruminants, has a complex life cycle with two intermediate hosts; the land snail and the ant. Human infection occurs by accidental ingestion of the second intermediate host. The present reported a patient suffered from recurrent acute chole-cystitis with chronic urinary schistosomiasis whose Kato stool examination showed Dicroceolium dendriticum eggs. He was successfully treated with Mirazid ${ }^{\circledR}$

Keywords: Egypt, Dicrocoelium dendriticum, schistosomiasis, treatment.

\section{Introduction}

Dicrocoelium dendriticum or the lancet liver fluke is a parasite of the bile ducts \& gall bladder of worldwide distribution among more than sixty mammalian hosts. However, the sheep, cattle, goats, deer, rabbits, equines, caprines and even dogs and cats other mammalians including man, but, spurious infection is the consequence of eating raw or undercooked animal liver; the eggs pass through the digestive tract unchanged (Burger et al, 2006). The human clinical symptoms of the true infection are neither uniform nor specific (Wilson, 1991).

This paper reported concomitant infection of Dicrocoelium dendriticum in a chronic schistosomiasis haematobium infected Egyptian old patient.

\section{Patient, Materials and Method}

A 62-year-old man from Beni-Sowif Governorate and he lived at Nag-Hammady City; Qena Governorate was referred for the laboratory examination. He suffered from chronic diarrhea with a copious of mucus in stool, and hematuria since 11 years with suspicion of bladder carcinoma after cystoscopy, another cystoscopy diagnose as a benign tumor, at 2009 he complained from vague abdominal pain and diagnosed as colonic stricture with benign tumor. Three years later he complained from repeated right hypochondria colicky pain and diagnosed as acute cholycysistis. He also complained from epigastric pain, upper endoscope was done and was diagnosed as gastritis.

Laboratory examination: CBC re-vealed eosinophilia, urine examination showed traces of bile acids and urinary tract infection and stool examination (Katz et al, 1970) revealed Dicroceolium dendriticum eggs. The patient was successfully treated with Mirazid ${ }^{\circledR}$ as two capsules on an empty stomach an hour before breakfast for seven successive days. After treatment, the patient was followed-up clinically and parasitological for one month.

\section{Discussion}

Mowlavi et al. (2015) stated that D. dendriticum spread together with sheep and goats westward throughout Europe from the Fertile Crescent during the 8000-6000year BC period and somewhat later southward into Africa, both spreads facilitated by the low specificity of that trematode species regarding the snail and ant intermediate hosts. In Egypt, Haridy et al. (2003) reported $D$. dendriticum in the sheep, goats and man in North Sinai Governorate. They added that infection is acquired by eating the second intermediate host (17 ants' species) with raw fruits, vegetables, herbs or even with the drinking water, and as to the first intermediate host, there was about 54 different species of land snails. They stated that in spite of the fact that the first and second intermediate hosts of $D$. dendriticum are available in Egypt, data about human and animal dicrocoeliasis was lacking.

Massoud et al. (2003) in North Sinai Gov- 
ernorate successfully treated two dicrocoeliasis dendriticum butchers patients; one with Praziquantel $^{\circledR}(25 \mathrm{mg} / \mathrm{kg}$ three times daily after meals, for 4 successive days) and the second one with Mirazid ${ }^{\circledR}$ (2 capsules of $300 \mathrm{mg}$ daily an hour before breakfast, for six successive days) as indicated clinically and parasitological. Also, they successfully treated dicrocoeliasis imported sheep and two naturally infected local bred goats with Oleo-resin solution $(6 \mathrm{ml}$ or $10 \mathrm{gm} \%$ equivalent to 2 Mirazid capsules one hour before breakfast) orally once daily for 4 successive days, and cure was indicated by the stool examination and macroscopic examination of the animals when slaughtered. Haridy et al. (2006) in Tanta City (Gharbia Governorate) reported $D$. dendreticum in sheep 5/100 (5\%), but neither dicrocoeliasis infection was in cattle or buffaloes. El-Shafie et al. (2011) in Giza Governorate reported zoonotic dicrocoeliasis dendriticum among a farmer's family and his domestic animals. The father and his wife were successfully treated with Triclabendazole ${ }^{\mathbb{R}}$ while the children and animals were successfully treated with Mirazid and Oleo-resin solution of Commiphora molmol respectively.

In the Arab Countries, dicrocoeliasis in man and/or animals was reported in Iraq (Wajdi and Nassir, 1983), Lebanon and Syria (Tohmé and Tohmé, 1977), Kuwait (Al Behbehani et al, 2003), Saudi Arabia (Abu Zinada, 1999; Omar et al, 1991; Helmy and Al Mathal, 2003; Al-Mathal and Fouad, 2004; AlMegrin, 2010; Albogami et al, 2015), Somalia (Nødgaard and Kristensen, 1995) Sudan (Sabbatani and Fiorino, 2009) and Syria (Yenikomshian and Berberian, 1934).

Abroad, dicrocoeliasis was reported in the Canadian sympatric elk and beef cattle (Beck et al, 2014), in Côte d'Ivoire in the non-human primates (Kouassi et al, 2015), in Ghanaian school children (Ofori et al, 2015), in Indian goats (Godara et al, 2014), in Italian patients and the imported beef cattle (Stancampiano et al, 2007), in Japan D. chinensis was reported in Iwate prefecture (Ohtori et al,
2014), in Malaysian edible animals (Ran et $a l, 2015)$, in Switzerland, dicrocoeliasis was the most significant parasite of llamas and alpacas (Hilbe et al, 2015), in Turkish University students (Köksal et al, 2010) and in Turkish patients and garden snails (Köse et al, 2015). Hatam-Nahavandi et al. (2015) in Iran stated that in recent years, decreasing annual rainfalls in some countries and population growth forced to a shortage of freshwater resources. Also, the recycled wastewaters were suggested for agricultural activities. They investigated the occurrence of helminth eggs and protozoan cysts or oocysts in human and livestock wastewaters. They identified in urban treatment plants included hookworms, Hymenolepis \& Rhabditis (or perhaps Strongyloides), Entamoeba, Isospora, Giardia, Chilomastix and Cryptosporidium, while in the slaughterhouses Trichuris, Trichostrongylus, Moniezia, Dicrocoelium, Fasciola, Entamoeba, Cryptosporidium, Eimeria and Giardia were isolated. They concluded that the efficacy of removal of nematode eggs, and not protozoan infective stages, in the urban wastewater treatment plants, was in compliance with the WHO parasitological guideline $(<1$ nematode/liter) required for unrestricted irrigation.

Generally speaking, $D$. dendriticum with $D$. hospes as being long and narrow, are generally confined to the more distal parts of the bile ducts. As a result most $D$. dendriticum infections of the biliary tree produce only mild symptoms. In the initial stages, there is leukocytosis, eosinophilia and traces of bile acids in the urine. On the more infection, slight anemia may ensue, the leukocytosis drops to normal level and eosinophila decreased to 5\%-7\% (Rosicky and Groschaft, 1982). Manga-González et al. (2004) reported significant increases in the hepatic enzyme activity as a pathogenic response to the dicrocoeliasis invasion that produced host-toxic metabolites. Usually, the dicrocoeliasis is accompanied by either a prolonged period of constipation or diarrhea, nausea and vomiting. Sometimes, the patients may complain of abdominal dis- 
comfort and pain in the right half of the abdomen and in the epigastrium radiating to the right shoulder and chronic watery diarrhea with slight elevation of liver function tests. In heavier infections, the bile ducts and biliary epithelium may become enlarged in addition to the generation of fibrous tissue surrounding the ducts causing an enlarged liver (hepatomegaly) or inflammation of the liver cirrhosis (Cengiz et al, 2010). In one unique case, $D$. dendriticum was associated with a skin rash urticaria (Sing et al, 2008).

Moreover, Khalil et al. (2013) stated that $D$. dendriticum, rather than Linguatula serrata or Fasciola hepatica, as the prime suspect in the pathogenesis of Lebanese people, halzoun syndrome. Hilbe et al. (2015) reported that liver flukes can induce proliferative changes in lung arteries in New World Camelids that resemble those seen with pulmonary arterial hypertension caused by human liver parasites. But, the degree of liver fluke infection was not correlated with the extent of liver damage, or with the amount of thoracic or abdominal effusion or pulmonary arterial changes. Pepe et al. (2015) studied the effects of $D$. dendriticum on cell proliferation, cell death mechanisms and oxidative stress induction was evaluated in hepatocellular carcinoma (HCC) cell lines (HepG2 \& HuH7) and found that the occurrence of an escape anti-apoptotic mechanism in HCC cells. They concluded that the role for $D$. dendriticum in the chronic oxidative stress and in the regulation of transformation processes in hepatic cell carcinoma warranting. Current public health prevention strategies have involved the condemnation of contaminated livers so as to eliminate any possibility for the food-borne infection (CDC, 2013).

\section{Conclusion}

Undoubtedly, the pathogenesis of dicrocoeliasis worldwide is more than was previously considered. The zoonotic dicrocoeliasis transmission could occur through the sheep, buffalo, rabbits, equines and/or even dogs and cats. Also, the imported beef must be inspected. Besides, the health care workers should keep in mind zoonotic parasitoids especially the rarely encountered dicrocoeliasis.

\section{References}

Abu Zinada, NY, 1999: Natural dicrocoeliasis in imported sheep, Jeddah, Saudi Arabia. J. Egypt. Soc. Parasitol. 29, 2:649-52.

Al-Behbehani, B, Mathew, TC, Dashti, HM, 2003: Ultrastructural studies on the tegument of Dicrocoelium dendritium Looss 1899. J. Egypt. Soc. Parasitol. 33, 1: 31-40.

Albogami, BM, Kelany, AH, Abu-Zinadah, O A, 2015: Prevalence of Dicrocoelium dendriticum infection in sheep at Taif Province, West Saudi Arabia. J. Egypt. Soc. Parasitol. 45, 2: 435-42

Al-Mathal, EM, Fouad, MA, 2004: Myrrh (Commiphora molmol) in treatment of human and sheep dicrocoeliasis dendriticum in Saudi Arabia. J. Egypt. Soc. Parasitol. 34, 2:713-20.

Al-Megrin, WA, 2010: Intestinal parasites infection among immunocompromised patients in Riyadh, Saudi Arabia. Pak. J. Biol. Sci. 13, 8:390-4.

Beck, MA, Goater, CP, Colwell, DD, van Paridon, BJ, 2014: Fluke abundance versus host age for an invasive trematode (Dicrocoelium dendriticum) of sympatric elk and beef cattle in southeastern Alberta, Canada. Int. J. Parasitol. Parasites Wildl. 3, 3:263-8

Burger, NC, Nesvadba, J, Nesvadba, Z, Busato, A, Gottstein B, 2006: The incidence of Dicrocoelium dendriticum in Emmental. Berl. Munch. Tierarztl. Wochenschr. 119, 7/8:324-9.

CDC, 2013: DPDx-Laboratory Identification of Parasitic Diseases of Public Health Concern. www.cdc. gov/dpdx/dicrocoeliasis/index.htm

Cengiz, ZT, Yilmaz, H, Dulger, AC, Cicek, M, 2010: Human infection with Dicrocoelium dendriticum in Turkey. Ann. Saudi Med. 30, 2:15961

Godara, R, Katoch, R, Yadav, A, Borah, MK, 2014: Dicrocoeliosis in goats in Jammu, India. J. Parasit. Dis. 38, 2:201-4.

Haridy, FM, El-Sherbiny, GT, Morsy, TA, 2006: Some parasitic flukes infecting farm animals in Al-Santa Center, Gharbia Governorate, Egypt. J. Egypt. Soc. Parasitol. 36, 1:259-64

Haridy, FM, Morsy, TA, Ibrahim, BB, AbdelAziz, A, 2003: A preliminary study on dicrocoeliasis in Egypt, with a general review. J. Egypt. Soc. Parasitol. 33:85-96.

Hatam-Nahavandi, K, Mahvi, AH, Mohebali, M, Keshavarz, H, Mobedi, I, et al, 2015: Detection of parasitic particles in domestic and urban 
wastewaters and assessment of removal efficiency of treatment plants in Tehran, Iran. J. Environ. Hlth. Sci. Eng. Jan 25;13:4. doi: 10.1186/s40201015-0155-5.

Helmy, MMF, Al-Mathal, EM, 2003: Human infection with Dicrocoelium dendriticum in Riyadh district (Saudi Arabia). J. Egypt. Soc. Parasitol. 33, 1:139-44.

Hilbe, M, Robert, N, Pospischil, A, Gerspach, C, 2015: Pulmonary arterial lesions in new world Camelids in association with Dicrocoelium dendriticum and Fasciola hepatica Infection. Vet. Pathol. 52, 6:1202-9.

Katz, NZ, Coelho, PMZ, Pellegrino, J, 1970: Evaluation of Kato quantitative method through the recovery of Schistosoma mansoni eggs added to human faeces. J. Parasitol. 56:1032-41.

Khalil, G, Haddad, C, Otrock, ZK, Jaber, F, Farra, A, 2013: Halzoun, an allergic pharyngitis syndrome in Lebanon: the trematode Dicrocoelium dendriticum as an additional cause. Acta Trop. 125, 1:115-8.

Köksal, F., Başlanti, I., Samasti, M. 2010: A retrospective evaluation of the prevalence of intestinal parasites in Istanbul, Turkey. Turkiye Parazitol. Derg. 34, 3:166-71.

Köse, M, Eser, M, Kartal, K, Bozkurt, MF, 2015: Infections of larval stages of Dicrocoelium dendriticum and Brachylaima sp. in brown garden snail, Helix aspersa, in Turkey. Korean J. Parasitol. 53, 5:647-51

Kouassi, RY, McGraw, SW, Yao, PK, Abou-Bacar, A, Brunet, J, et al, 2015: Diversity and prevalence of gastrointestinal parasites in seven non -human primates of the Taï National Park, Côte d'Ivoire. Parasite. 22:1. doi: 10.1051/ parasite.

Massoud, A, Morsy, TA, Haridy, FM, 2003: Treatment of Egyptian dicrocoeliasis in man and animals with Mirazid. J. Egypt. Soc. Parasitol. 33, 2:437-42.

Mowlavi, G, Mokhtarian, K, Makki, MS, Mobedi, I, Masoumian, M, et al, 2015: Dicrocoelium dendriticum found in a Bronze age cemetery in western Iran in the pre-Persepolis period: The oldest Asian Palaeo finding in the present human infection hottest spot region. Parasitol. Int. 64, 5: 251-5.

Nødgaard, H, Kristensen, B, 1995: Dicrocoelium dendriticum egg in feces of 2 Somali boys in Denmark: Transitory elimination after arrival to Denmark. Ugeskr. Laeger. 157, 29:4140.
Ofori, M, Bogoch, II, Ephraim, RK, 2015: Prevalence of Dicrocoelium dendriticum ova in Ghanaian school children. J. Trop. Pediatr. 61, 3:22930.

Ohtori, M, Aoki, M, Itagaki, T, 2014: Distinct distribution of Dicrocoelium dendriticum and D. chinensis in Iwate Prefecture, Japan, and a new final host record for $D$. chinensis. J. Vet. Med. Sci. 76, 10:1415-7.

Omar, MS, Abu-Zeid, HA, Mahfouz, AA, 1991: Intestinal parasitic infections in schoolchildren of Abha (Asir), Saudi Arabia. Acta Trop. 48, 3:195-202.

Pepe, P, Castellano, M, Alfano, S, Della Pepa, ME, Tirino, V, et al, 2015: Dicrocoelium dendriticum induces autophagic vacuoles accumulation in human hepatocarcinoma cells. Vet. Parasitol. 212, 3/4:175-80.

Sabbatani, S, Fiorino, S, 2009: Contribution of palaeopathology to defining the pathocoenosis of infectious diseases: (Part 2). Infez. Med. 17, 1: 47-63.

Scheid, G, Mendheim, H, Amenda, R, 1950: Die Lanzetegel infection (Dicrocoeliasis) beim, Menschennebst Mitteilung einesneuen Falles. Zeitschrift Tropenmed. Parasitol. 2:142-7.

Sing, A, Tybus, K, Fackler, I, 2008: Acute urticaria associated with Dicrocoelium dendriticum infestation. Indian J. Med. Microbiol. 26, 1:97-8.

Stancampiano, L, Corradini, D, Bulgarelli, M, Micagni, G, 2007: Parasites of the digestive tract in beef cattle imported from France to Italy. Parasitol. 49, 1/2:101-6.

Tan, TK, Low, VL, Lee, SC, Panchadcharam, C, Tay, ST, et al, 2015: Detection of Schistosoma spindale ova and associated risk factors among Malaysian cattle through coprological survey. Jpn. J Vet. Res. 63, 2:63-71.

Tohmé, H, Tohmé, G, 1977: Intermediary hosts of Dicrocoelium lanceolatum in Lebanon and Syria. Ann. Parasit. Hum. Comp. 52, 2:1-5.

Wajdi, N, Nassir, JK, 1983: Studies on the parasitic helminths of slaughtered animals in Iraq: Parasitic helminthes of the liver of herbivores. Ann. Trop. Med. Parasitol. 77, 6:583-5.

Yenkomshian, HA, Berberian, DA, 1934: The occurrence and distribution of human helminthiasis in Syria and Lebanon, with case reports on $\mathrm{Di}$ crocoelium dendriticum and Hymenolepis nana infestations. Trans. R. Soc. Trop. Med. Hyg. 27: 425-31. 